\title{
Clinical and Therapeutic Approach to Hospitalized COVID-19 Patients: A Pediatric Cohort in Portugal
}

\author{
Abordagem Clínica e Terapêutica de Doentes Internados \\ por COVID-19: Uma Coorte Pediátrica em Portugal
}

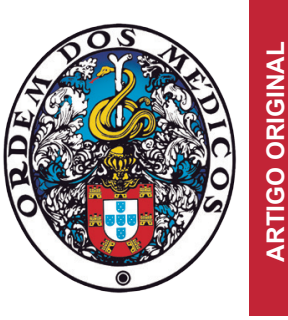

Bárbara Martins SARAIVA $\triangle 1$, Ana Margarida GARCIA ${ }^{1}$, Tiago Milheiro SILVA ${ }^{1}$, Catarina GOUVEIA 1 , Maria João BRITO ${ }^{1}$ Acta Med Port 2021 Apr;34(4):283-290 - https://doi.org/10.20344/amp.15360

\begin{abstract}
Introduction: Coronavirus disease 2019, or COVID-19, in children is usually a mild disease, but severe illness has been reported. Currently, the therapy benefits of antiviral experimental drugs are still uncertain. The main aim of this study is to describe the experience of a level III hospital regarding therapeutic management of hospitalized children with COVID-19 and to characterize clinical features and evolution.

Material and Methods: This is a descriptive study of patients with COVID-19 in a level III pediatric hospital in Portugal between March and June 2020. Experimental drugs were administered according to the best scientific evidence at the time as 'off-label use'.

Results: Among 200 children with SARS-CoV-2 infection, 37 were admitted due to COVID-19. Median age was one year (23 days 18 years), $43 \%$ had comorbidities and 20/37 (54\%) received antiviral therapy. Hydroxychloroquine was administered in 13 patients, in monotherapy or combined with lopinavir/ritonavir or azithromycin. Lopinavir/ritonavir was administered in eight patients and three children were treated with remdesivir. The patients who were treated had pneumonia (14), multisystem inflammatory syndrome in children (2), sepsis (2), myocarditis (1), acute respiratory distress syndrome (1), and mild illness with comorbidities (3). Other therapies included methylprednisolone and immunoglobulin (3), enoxaparin (2), antibiotics (16), oxygen (7), corticosteroids, and other inhaled therapy (16).

Discussion: Several treatment approaches have been proposed for severe COVID-19, even though none of them had been proven effective or approved for small children. Currently, remdesivir is approved for children aged above 12 years-old. Although $54 \%$ of our patients were treated with antivirals, it is important to understand that the favorable clinical evolution could be related with the natural course of the disease.

Conclusion: A significant proportion of our population presented severe and critical disease, was hospitalized and received treatment according to the most recent data, although most patients had mild disease. COVID-19 treatment in children is a clinical challenge and clinical trials are urgently needed.
\end{abstract}

Keywords: Antiviral Agents/therapeutic use; Child; COVID-19; Portugal; SARS-CoV-2

\section{RESUMO}

Introdução: A infeção SARS-CoV-2 em idade pediátrica cursa maioritariamente com doença ligeira. No entanto, pode ocorrer doença grave, ainda que com menor frequência. Atualmente, os benefícios das terapêuticas antivirais experimentais ainda são incertos. $O$ objetivo deste estudo consiste em descrever a experiência de um hospital terciário no tratamento de crianças internadas por COVID-19 e caracterizar a clínica e evolução.

Material e Métodos: Estudo descritivo em doentes até aos 18 anos de idade, internados com COVID-19 num hospital pediátrico de nível III em Portugal, de março a junho de 2020. Os fármacos antivirais foram administrados em regime de off-label.

Resultados: Identificaram-se 200 casos de infeção SARS-CoV-2, dos quais 37 foram internados com COVID-19. A idade mediana foi de um ano (23 dias - 18 anos), 43\% apresentavam comorbilidades e 20/37 (54\%) receberam terapêutica antiviral. A hidroxicloroquina foi administrada em 13 doentes em monoterapia ou associada a lopinavir/ritonavir ou azitromicina. O lopinavir/ritonavir foi utilizado em oito doentes e três doentes receberam remdesivir. O tratamento antiviral foi aplicado a doentes com pneumonia (14), sépsis (2), síndrome inflamatório multisistémico pediátrico (2), síndrome dificuldade respiratória aguda (1), miocardite (1) e crianças com doença ligeira e comorbilidades (3). Realizaram-se também outras terapêuticas que incluíram metilprednisolona e imunoglobulina (3), enoxaparina (2), antibióticos (16), oxigenoterapia (7) e broncodilatadores e corticoides inalados (16).

Discussão: Diversas abordagens terapêuticas têm sido sugeridas para casos graves de COVID-19, embora nenhuma seja até à data considerada eficaz, ou esteja aprovada em crianças pequenas. Atualmente, o remdesivir está aprovado para idades superiores a 12 anos. Apesar de $54 \%$ dos nossos doentes terem sido tratados com antivirais, é importante compreender que a evolução favorável poderá ter estado associada à evolução natural da doença.

Conclusão: Uma percentagem significativa da população apresentou doença grave a crítica, com necessidade de internamento e tratamento, este último definido com base nas recomendações da comunidade científica à data, embora a maioria apresentasse doença ligeira. O tratamento da COVID-19 em idade pediátrica é um desafio, sendo urgente realizar ensaios clínicos relativos a esta matéria. Palavras-chave: Antivirais/uso terapêutico; COVID-19; Criança; Portugal; SARS-CoV-2

\section{INTRODUCTION}

In December 2019, a novel coronavirus was found to be responsible for a new outbreak of pneumonia in the city of Wuhan, China. ${ }^{1}$ The new coronavirus was identified on

the $3^{\text {rd }}$ January, $2020 .^{2}$ It was named severe acute respiratory syndrome coronavirus 2, SARS-CoV-2, as it showed a $79.5 \%$ genome similarity with SARS-CoV, ${ }^{3}$ which is

\footnotetext{
1. Pediatric Infectious Diseases Unit. Hospital Dona Estefânia. Centro Hospitalar Universitário de Lisboa Central. Lisboa. Portugal.

$\triangle$ Autor correspondente: Bárbara Martins Saraiva. barbara.saraiva@chlc.min-saude.pt

Recebido: 20 de novembro de 2020 - Aceite: 22 de fevereiro de 2021 - First published: 12 de março de 2021 - Online issue published: 01 de abril de 2021 Copyright @ Ordem dos Médicos 2021
} 
responsible for coronavirus disease-2019, COVID-19. ${ }^{1}$

A pandemic was declared on the $11^{\text {th }}$ March, $2020^{4}$ and the first COVID-19 case in Portugal was confirmed on the $2^{\text {nd }}$ March. ${ }^{5}$ Until 23 $3^{\text {th }}$ of February, 2021, 111419939 cases have been diagnosed worldwide, with 2470772 deaths. ${ }^{6}$ At the same time, in Portugal, $14.82 \%$ of COVID-19 cases were diagnosed in children. ${ }^{5}$

COVID-19 usually presents as a mild illness in children. ${ }^{7,8}$ Although less frequently, children can present severe illness, requiring hospitalization, ${ }^{8,9}$ and a novel multisystem inflammatory syndrome in children (MIS-C) was observed with severe cases overlapping toxic shock syndrome and atypical Kawasaki disease. ${ }^{10,11}$

Treatments previously used in SARS-CoV, MERS-CoV, and Ebola virus were initially considered for COVID-19 ${ }^{12}$ and at least two hundred drugs are being researched. ${ }^{13}$ Different treatment approaches are being adopted by each country, ${ }^{14}$ and even the World Health Organization (WHO) recommendations primarily focus on supportive management. ${ }^{13-15}$ At the moment, in Portugal, remdesivir is the only antiviral approved for adults and children aged 12 and above, ${ }^{16}$ as it has been shown to reduce time recovering from COVID-19 low respiratory tract infection in adults. ${ }^{17}$ In addition, methylprednisolone (MPDN), dexamethasone, and immunoglobulin (NHIG) are being used as immunomodulatory treatments. ${ }^{14,18}$

Most clinical trials primarily focus on adult cohorts and the evidence in pediatrics is still limited. ${ }^{19}$ No studies on the therapeutic management of hospitalized COVID-19 pediatric patients, in Portugal, have been published yet. Therefore, the main goal of this study is to describe the experience in a level III pediatric Portuguese referral hospital on the therapeutic management of hospitalized pediatric patients with COVID-19 and also to characterize clinical features and evolution.

\section{MATERIAL AND METHODS Study population}

A descriptive study of children and adolescents aged 18 and under, with SARS-CoV-2 infection, hospitalized in a level III pediatric referral hospital, from the $7^{\text {th }}$ March, 2020 to the $14^{\text {th }}$ June, 2020.

\section{Data collection}

Hospital clinical records were used for the data collection of each patient. Demographic, clinical, and epidemiological data, including age, sex, confirmed exposure to SARS-CoV-2 infection, symptoms in admission, previous comorbidities, COVID-19 diagnosis, presence of coinfections, laboratory findings, and complete therapeutic approach (antivirals and other therapies) was collected. Adverse drug reactions of medications and post-discharged sequelae were also collected.

\section{Study definitions}

SARS-CoV-2 infection was diagnosed by real-time reverse transcription polymerase chain reaction (RT-PCR) in samples of nasopharyngeal and throat swabs and/or aspiration of nasopharyngeal secretions. MIS-C was also considered when antibodies to SARS-CoV-2 were detected. Children with mild illness that were admitted due to the initial epidemic contention phase, social motives, and asymptomatic children with SARS-CoV-2 infection admitted due to other clinical reasons were excluded. Patients were classified into mild, moderate, severe, and critical cases according to the World Health Organization (WHO) criteria (Table 1)..$^{15}$

\section{Treatment}

The treatment approach was decided according to the best scientific evidence available during the study period. Hydroxychloroquine (HCQ) was administered under a cardiotoxicity monitoring protocol through regular electrocardiograms and clinical surveillance. The loading dose was 6.5 $\mathrm{mg} / \mathrm{kg} /$ dose, twice a day (bid) on the first day, followed by $6.5 \mathrm{mg} / \mathrm{kg} / \mathrm{day}$, bid on the next four days (maximum dose of $400 \mathrm{mg} /$ day). Lopinavir/ritonavir (LPV/r) was administered for seven to 14 days, bid, in children treated in the first 96 hours after disease onset. Doses were given according to the children's weight: $16 / 4 \mathrm{mg} / \mathrm{kg} /$ dose $(<7 \mathrm{~kg}) ; 12 / 3 \mathrm{mg} / \mathrm{kg} /$ dose (7 - $15 \mathrm{~kg}) ; 10 / 2.5 \mathrm{mg} / \mathrm{kg} /$ dose (15 - $40 \mathrm{~kg}$ ); 400/100 $\mathrm{mg} /$ dose (> $40 \mathrm{~kg}$ ). Remdesivir was delivered during five to 10 days, $5 \mathrm{mg} / \mathrm{kg}$ (max. $200 \mathrm{mg}$ ) on the first day of treatment and $2.5 \mathrm{mg} / \mathrm{kg}$ (max. $100 \mathrm{mg}$ ) on the following days. Azithromycin was administered for five days, once a day, 10 $\mathrm{mg} / \mathrm{kg} /$ day (max. $500 \mathrm{mg} /$ day). All antiviral therapies were administered after informed consent signed by the parents

Table 1 - Clinical respiratory syndromes associated with COVID-19 15

\begin{tabular}{|c|c|}
\hline Asymptomatic & Without any symptoms, confirmed by laboratory tests \\
\hline Mild illness & $\begin{array}{l}\text { Respiratory infection of the upper tract: Fever, cough, fatigue, anorexia, myalgia, sore throat, rhinorrhea, } \\
\text { headache. Rarely with nausea, vomiting and diarrhea. }\end{array}$ \\
\hline Moderate case & $\begin{array}{l}\text { Pneumonia with non-severe signs of respiratory distress (tachypnoea }<2 \text { months: } \geq 60 \mathrm{cpm} ; 2-11 \text { months: } \\
\geq 50 \mathrm{cpm} ; 1-5 \text { years: } \geq 40 \mathrm{cpm},>5 \text { years: }>30 \mathrm{cpm} \text {, moderate recession), } \mathrm{SpO}_{2} \geq 93 \%\end{array}$ \\
\hline Severe case & $\begin{array}{l}\text { Pneumonia with severe signs of respiratory distress (Central cyanosis or } \mathrm{SpO}_{2}<93 \% \text {, severe tachypnoea } \\
(<12 \text { months: }>70 \mathrm{cpm} ;>12 \text { months: }>50 \mathrm{cpm} \text { ), chest retractions, grunting, nasal flaring), severe anorexia, } \\
\text { lethargy/decreased level of consciousness, convulsions }\end{array}$ \\
\hline Critical case & Acute respiratory distress syndrome (ARDS), sepsis, septic shock \\
\hline
\end{tabular}


or caretakers and the approval by the pharmacy committee at our hospital. MPDN was given as $2 \mathrm{mg} / \mathrm{kg} / \mathrm{day}$ for five days followed by steroid tapering and NHIG was administered intravenously for two days, $1 \mathrm{~g} / \mathrm{kg} /$ day.

\section{Statistical analysis}

The data was mostly presented as categorical variables except for age. Also, age does not follow a normal distribution.

Chi-square and Fischer's exact probability test were used to study associations between categorical variables. The Chi-square test was used to analyze the statistical significance between the presence of coinfections or comorbidities and treatment. It was also used to study the statistical significance between the presence of anemia, lymphopenia, elevated C-reactive protein, fibrinogen, D-dimer, ferritin or troponin and treatment. Finally, the Fischer's exact probability test was used to study statistical significance between elevated procalcitonin, lactate dehydrogenase or brain natriuretic peptide and treatment. $P$-values of $<0.05$ were considered statistically significant. All the analyses were carried out using SPSS $26^{\circledR}$.

\section{RESULTS}

A total of 200 cases of SARS-CoV-2 infection were followed in this period. Among these, 80 were hospitalized, but only 37 of them were admitted due to COVID-19.

Twenty-one (57\%) were female, the median age was one year old (range 23 days - 18 years), with $13(35 \%)$ over 10 years old, $12(32 \%)$ between one to 12 months and three $(8 \%)$ were newborns. Sixteen $(43 \%)$ patients had preexisting medical conditions. The most frequent symptoms were cough $(26 ; 70 \%)$, fever $(24 ; 65 \%)$, and respiratory distress $(20 ; 54 \%)$ (Table 2).

Patients with COVID-19 were admitted due to pneumonia $(14 ; 38 \%)$, sepsis $(2 ; 5 \%)$, MIS-C $(2 ; 5 \%)$, myocarditis without MIS-C criteria $(1 ; 3 \%)$, acute respiratory distress syndrome (ARDS) $(1 ; 3 \%)$, mild illness $(10 ; 27 \%)$, or mild illness with severe comorbidities (7; 19\%). Four children (11\%) were admitted to the intensive care unit (ICU): a 2-month-old girl with bronchopulmonary dysplasia and chronic renal disease with pneumonia; a 10-year-old girl with dilated cardiomyopathy and myocarditis; a 13-year-old boy with MIS-C with multi-organ dysfunction and a 4-monthold boy with lymphangioleiomyomatosis with ARDS and cardiac dysfunction (Table 2).

Table 2 - Demographic, epidemiological, clinical characteristics of 37 COVID-19 hospitalized children

\begin{tabular}{|c|c|c|c|c|c|}
\hline Demography & n (\%) & Symptoms & n (\%) & Children with comorbidities & n (\%) \\
\hline Sex & & Cough & $26(70 \%)$ & Total of children with comorbidities & $16(43 \%)$ \\
\hline Female & $21(57 \%)$ & Fever & $24(65 \%)$ & Asthma & $3(8 \%)$ \\
\hline \multirow[t]{2}{*}{ Male } & $16(43 \%)$ & Respiratory distress & $20(54 \%)$ & Congenital heart disease ${ }^{a}$ & $3(8 \%)$ \\
\hline & & Vomiting & $15(41 \%)$ & Chromosomal abnormalities ${ }^{\mathrm{b}}$ & $2(5 \%)$ \\
\hline Age & & Anorexia & $14(38 \%)$ & Chronic kidney disease & $2(5 \%)$ \\
\hline Newborn (<28 days) & $3(8 \%)$ & Rhinorrhea & $13(35 \%)$ & JIA under immunosuppression & $2(5 \%)$ \\
\hline $1-12$ months & $12(32 \%)$ & Fatigue & $10(27 \%)$ & Short bowel syndrome & $1(3 \%)$ \\
\hline $1-5$ years & $5(14 \%)$ & Diarrhea & $8(22 \%)$ & Sickle cell anemia & $1(3 \%)$ \\
\hline $5-10$ years & $4(11 \%)$ & Skin lesions & $7(19 \%)$ & Bronchopulmonary dysplasia & $1(3 \%)$ \\
\hline$\geq 10$ years & $13(35 \%)$ & Sore throat & $6(16 \%)$ & Lymphangioleiomyomatosis (LAM) & $1(3 \%)$ \\
\hline Minimum age & 23 days & Myalgia & $5(14 \%)$ & None & $21(57 \%)$ \\
\hline Maximum age & 18 years & Chest pain & $4(11 \%)$ & & \\
\hline Median age & 1 year & Anosmia & $3(8 \%)$ & Patients with comorbidities treated & \\
\hline \multirow[t]{3}{*}{ IQR } & {$[0,56 ; 10]$} & Headache & $3(8 \%)$ & $p$-value $(95 \% \mathrm{Cl})^{c}$ & $11 / 16(69 \%)$ \\
\hline & & Bilateral conjunctivitis & $2(5 \%)$ & & $p=0.117$ \\
\hline & & Convulsion & $1(3 \%)$ & & \\
\hline Exposure COVID-19 & n (\%) & & & COVID-19 diagnoses in admission & n (\%) \\
\hline Confirmed & $21(57 \%)$ & & & Mild illness & $10(27 \%)$ \\
\hline \multirow[t]{6}{*}{ Unknown } & $16(43 \%)$ & & & Mild illness with comorbidities & $7(19 \%)$ \\
\hline & & & & Pneumonia & $14(38 \%)$ \\
\hline & & & & Sepsis & $2(5 \%)$ \\
\hline & & & & MIS-C + Myocarditis & $2(5 \%)$ \\
\hline & & & & ARDS & $1(3 \%)$ \\
\hline & & & & Myocarditis & $1(3 \%)$ \\
\hline
\end{tabular}

ARDS: acute respiratory distress syndrome; Cl: confidence interval; Immunosup: immunosuppressive therapy; IQR: interquartile range; JIA: juvenile idiopathic arthritis; MIS-C: multisystem inflammatory syndrome in children; LAM: Iymphangioleiomyomatosis.

a Ostium secundum interatrial communication; dilated cardiomyopathy, perimembranous interventricular communication; ${ }^{\mathrm{b}}$ Trisomy 18 ; $15 \mathrm{q}$ microdeletion syndrome; ${ }^{\mathrm{C}}$ Chi-square test was used to calculate statistical significance between the presence of comorbidities and treatment which was not found. 
Table 3 - Coinfection and laboratory workup of 37 COVID-19 hospitalized children

\begin{tabular}{|c|c|c|c|c|c|c|}
\hline Patients with coinfections & n (\%) & & Laborator & $y$ findings ${ }^{* *}$ & & \\
\hline Total of patients with coinfections & $13(35 \%)$ & & Tot & Trea & & \\
\hline Rhinovirus & $5(14 \%)$ & Parameter & of patients & antivirals & 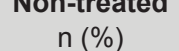 & $\begin{array}{l}p \text {-value } \\
(95 \% \mathrm{Cl})^{\text {b }}\end{array}$ \\
\hline Adenovirus & $3(8 \%)$ & & & & & \\
\hline Mycoplasma pneumoniae & $1(3 \%)$ & Hemoglobin $<11.0 \mathrm{~g} / \mathrm{L}$ & $24 / 37(6$ & $\%)$ & $10 / 17$ & 447 \\
\hline Enterovirus & $1(3 \%)$ & Lymphocytes < $2.7 \times 10^{9} / \mathrm{L}$ & $17 / 37(46 \%)$ & $9 / 20(45 \%)$ & $8 / 17(47 \%)$ & $p=0.431$ \\
\hline fluen & & $\mathrm{CRP}>5.0 \mathrm{mg} / \mathrm{L}$ & $24 / 37(64 \%)$ & $15 / 20(75 \%)$ & $9 / 17(53 \%)$ & $p=0.699$ \\
\hline & & Procalcitonin $>0.5 \mathrm{ng} / \mathrm{mL}$ & $7 / 37(19 \%)$ & $7 / 20(35 \%)$ & $0 / 17(0 \%)$ & $p=0.680$ \\
\hline Pneumocystis jirovecii & $2\left(5^{\circ}\right.$ & IL $6>6 \mathrm{pg} / \mathrm{mL}$ & $6 / 8(16 \%)$ & $6 / 8(75 \%)$ & $0 / 0(0 \%)$ & $* * *$ \\
\hline Influenza $B$ & $1(2 \%)$ & Fibrinogen $>1.70 \mathrm{~g} / \mathrm{L}$ & $23 / 37(62 \%)$ & $13 / 20(65 \%)$ & $10 / 17(59 \%)$ & $p=0.699$ \\
\hline Metapneumovirus & $1(3 \%)$ & D-dimer $>230 \mu \mathrm{g} / \mathrm{L}$ & 29/37 (78\%) & $16 / 20(80 \%)$ & $13 / 17(76 \%)$ & $p=0.763$ \\
\hline Respiratory syncytial virus & $1(3 \%)$ & Ferritin > $100 \mathrm{ng} / \mathrm{mL}$ & $18 / 37(49 \%)$ & $8 / 20(40 \%)$ & $10 / 17(59 \%)$ & $p=0.134$ \\
\hline & & Troponin - I > $1.9 \mathrm{pg} / \mathrm{mL}$ & $14 / 37(38 \%)$ & $11 / 20(55 \%)$ & $3 / 17(18 \%)$ & $p=0.330$ \\
\hline $\mathrm{r}$ & $4(11 \%)$ & $\mathrm{LDH}>300 \mathrm{U} / \mathrm{L}$ & $32 / 37(86 \%)$ & $18 / 20(90 \%)$ & $14 / 17(82 \%)$ & $p=1.000$ \\
\hline None & $24(65 \%)$ & $\mathrm{BNP}>100 \mathrm{pg} / \mathrm{mL}$ & $8 / 12(67 \%)$ & $8 / 10(80 \%)$ & $0 / 2(0 \%)$ & $p=0.005$ \\
\hline
\end{tabular}

Patients with coinfections treated $7 / 13(54 \%)$

$p$ value $(95 \% \mathrm{Cl})^{\text {a }} \quad(p=0.985)$

BNP: brain natriuretic peptide; Cl: confidence interval; CRP: C- reactive protein; LDH: lactate dehydrogenase; IL6: interleukin-6.

${ }^{a}$ Chi-square test was used to calculate statistical significance between the presence of coinfections and treatment which was not found. ${ }^{b}$ Statistical significance between the presence of anemia, lymphopenia, elevated CRP, fibrinogen, D-dimer, ferritin or troponin and treatment was calculated by the Chi-square test. Statistical significance between elevated procalcitonin, LDH or BNP and treatment was calculated by Fischer's exact probability test. Elevated BNP was the only laboratory parameter that showed a statistically significant association with treatment. ** Most laboratory workup was analyzed from the whole population ( $\mathrm{n}=37$, among which 20 were treated and 17 non-treated), except BNP, which was only analyzed in 12 patients - 10 treated and two non-treated -, and IL-6, requested in eight children, all of them treated. ${ }^{* * *}$ As we do not present information about IL-6 for non-treated patients, it was not possible to analyse a statistic association between treatment and variation of IL-6.

Coinfections were detected by polymerase chain reaction (PCR) and reported in $13(35 \%)$ children: rhinovirus (5; 14\%), adenovirus (3; 8\%), Mycoplasma pneumoniae (1; $3 \%)$, Pneumocystis jiiroveci $(2 ; 5 \%)$, and influenza B (1; $3 \%)$. Four (11\%) patients presented coinfection with more than one agent (Table 3).

Laboratory workup showed anemia $(24 ; 65 \%)$, elevated lactate dehydrogenase (LDH) (32; 86\%), D-dimer (29; $78 \%$ ), and C-reactive protein (CRP) (24; 65\%). (Table 3).

Antiviral therapy was proposed for 20 (59\%) patients, including mild disease with comorbidities (3), and moderate (5), severe (6), or critical (6) disease. No statistically significant association was found between the presence of comorbidities ( $p=0.117)$ or coinfections $(p=0.985)$ and treatment. (Tables 2 and 3 ). Also, statistical significance was studied between each laboratory parameter and treatment (Table 3), but it was only significant between elevated brain natriuretic peptide (BNP) and treatment $(p=0.005)$.

Hydroxychloroquine (HCQ) was administered in 13 (35\%) patients, in monotherapy $(8 ; 22 \%)$ or combined with lopinavir/ritonavir (LPV/r) $(4 ; 11 \%)$ or with azithromycin $(1$; $3 \%$ ) when Mycoplasma pneumoniae coinfection was present. LPV/r was administered in $8(22 \%)$ patients (five in monotherapy) and three (8\%) were treated with remdesivir (Table 4).

Children admitted due to mild illness without risk factors (10; $27 \%$ ) did not receive therapy. In mild disease with preexisting medical conditions $(7 ; 19 \%)$, therapy was decided on a case-by-case basis.

Focusing on moderate cases of pneumonia $(7 ; 19 \%)$, two patients $(5 \%)$ did not receive antiviral treatment due to favorable clinical evolution. The other cases of pneumonia (5; 14\%) were treated with HCQ $(1 ; 3 \%)$, LPV/r (2; 5\%), and HCQ combined with LPV/r (2; 5\%) (Table 5). Cases of hypoxemic pneumonia with severe signs of respiratory distress $(6 ; 16 \%)$ were treated with $\mathrm{HCQ}(3 ; 8 \%)$, and $\mathrm{HCQ}$ combined with LPV/r $(2 ; 5 \%)$ or azithromycin (1; 3\%) when coinfection with Mycoplasma pneumoniae was present. Critical cases $(7 ; 19 \%)$ included sepsis in a patient with less than three months of age treated with LPV/r (2; 5\%); MIS-C

Table 4 - Therapies administered in 37 COVID-19 hospitalized children

\begin{tabular}{lc}
\hline Antiviral therapy & $\mathbf{n}(\%)$ \\
\hline HCQ & $8(22 \%)$ \\
LPV/r & $4(11 \%)$ \\
HCQ + LPV/r & $4(11 \%)$ \\
HCQ + azithromycin & $1(3 \%)$ \\
Remdesivir & $3(8 \%)$ \\
Total number of children with antiviral therapy & $20(54 \%)$ \\
No antiviral therapy & $17(46 \%)$ \\
\hline Immunomodulatory therapy & $\mathbf{n}(\%)$ \\
\hline Methylprednisolone (MPDN) & $3(8 \%)$ \\
Immunoglobulin (NHIG) & $3(8 \%)$ \\
\hline Other therapies & $\mathbf{n}(\%)$ \\
\hline Antibiotics & $16(43 \%)$ \\
Enoxaparin & $2(5 \%)$ \\
Oseltamivir & $1(3 \%)$ \\
Oxygen & $7(19 \%)$ \\
Inhaled bronchodilators & $16(43 \%)$ \\
Inhaled corticosteroids & $16(43 \%)$ \\
Invasive mechanical ventilation & $3(8 \%)$ \\
Inotropic support & $3(8 \%)$ \\
\hline
\end{tabular}


Table 5 - Therapeutic management according to clinical syndrome in 37 COVID-19 hospitalized children

\begin{tabular}{|c|c|c|c|c|c|}
\hline Clinical syndrome (WHO) & n $(\%)$ & COVID-19 diagnoses & n (\%) & Treatment approach & $\mathbf{n}(\%)$ \\
\hline Mild illness + No risk factor & $10(27 \%)$ & Mild illness & $10(27 \%)$ & No AVT & $10(27 \%)$ \\
\hline Mild illness + Comorbidities & $7(19 \%)$ & Comorbidities & $7(19 \%)$ & $\begin{array}{l}\text { HCQ } \\
\text { No AVT }\end{array}$ & $\begin{array}{c}3(8 \%) \\
4(11 \%)\end{array}$ \\
\hline Moderate case & $7(19 \%)$ & Pneumonia & $7(19 \%)$ & $\begin{array}{l}\mathrm{HCQ} \\
\mathrm{LPV} / \mathrm{r} \\
\mathrm{HCQ}+\mathrm{LPV} / \mathrm{r} \\
\text { No AVT }\end{array}$ & $\begin{array}{l}1(3 \%) \\
2(5 \%) \\
2(5 \%) \\
2(5 \%)\end{array}$ \\
\hline Severe case & $6(16 \%)$ & Pneumonia & $6(16 \%)$ & $\begin{array}{l}\mathrm{HCQ} \\
\mathrm{HCQ}+\mathrm{LPV} / \mathrm{r} \\
\mathrm{HCQ}+\text { azithromycin }\end{array}$ & $\begin{array}{l}3(8 \%) \\
2(5 \%) \\
1(3 \%)\end{array}$ \\
\hline \multirow[t]{6}{*}{ Critical case } & $7(19 \%)$ & Sepsis ${ }^{a}$ & $2(5 \%)$ & $\mathrm{LPV} / \mathrm{r}$ & $2(5 \%)$ \\
\hline & & Pneumonia ${ }^{\mathrm{b}}$ & $1(3 \%)$ & No AVT & $1(3 \%)$ \\
\hline & & Myocarditis ${ }^{\mathrm{b}}$ & $1(3 \%)$ & Remdesivir & $1(3 \%)$ \\
\hline & & MIS-C with multi-organ dysfunction ${ }^{b}$ & $1(3 \%)$ & $\mathrm{HCQ}+\mathrm{MPDN}+\mathrm{NHIG}$ & $1(3 \%)$ \\
\hline & & MIS-C with myocarditis & $1(3 \%)$ & Remdesivir + MPD + NHIG & $1(3 \%)$ \\
\hline & & ARDS $^{b}$ & $1(3 \%)$ & Remdesivir + MPD + NHIG & $1(3 \%)$ \\
\hline
\end{tabular}

a Two patients aged under three months of age with viral sepsis upon admission; ${ }^{\text {b }}$ Four patients admitted in the ICU; ARDS: acute respiratory distress syndrome; HCQ: hydroxychloroquine; IMV: invasive mechanical ventilation; LPV/r: lopinavir/ritonavir; MPDN: methylprednisolone; MIS-C: multisystem inflammatory syndrome in children; NHIG: normal human immunoglobulin; No AVT: no antiviral treatment

with multi-organ dysfunction treated with $\mathrm{HCQ}(1 ; 3 \%)$ and three patients treated with remdesivir: the child with dilated cardiomyopathy and myocarditis $(1 ; 3 \%)$; MIS-C with myocarditis $(1 ; 3 \%)$; and ARDS $(1 ; 3 \%)$. One critical patient with pneumonia did not receive treatment according to the clinical evolution.

Clinical or laboratory improvement was observed usually 24 to 72 hours after the beginning of antiviral therapy.

NHIG associated with MPDN was used in children with MIS-C $(2 ; 5 \%)$ and ARDS $(1 ; 3 \%)$ with a favorable evolution after 24 to 48 hours of treatment. Antibiotics were used in $16(43 \%)$ patients due to suspected respiratory bacterial infection, including ceftriaxone, amoxicillin with clavulanate, cefuroxime, and clindamycin. Infants less than three months old were treated with ampicillin, cefotaxime, and gentamycin. MIS-C patients were initially treated with vancomycin, ceftriaxone, and clindamycin. Two patients with Pneumocystis jiiroveci coinfection received cotrimoxazole. Oseltamivir was used in a patient with influenza B coinfection (Table 4).

Oxygen therapy was required in seven (19\%) patients during a median of five days and other three (8\%) required invasive mechanical ventilation (IMV) for a median of eight days. Inhaled therapy with bronchodilators and corticosteroids was used in 16 (43\%) patients. Prophylactic enoxaparin was administered in two adolescents: one with sickle-cell disease and severe COVID-19 pneumonia and the other with MIS-C with multi-organ dysfunction. Inotropic support was needed in patients with myocarditis $(1 ; 3 \%)$, MIS-C (1; $3 \%$ ) and ARDS (1;3\%).

Adverse drug reactions were seen in three patients who received $L P V / r$ with nausea and vomiting, but with no need to discontinue therapy. Among the 13 patients who received $H C Q$, regular electrocardiograms were undertaken and only two had to discontinue HCQ temporarily (24 hours) due to prolonged QT interval (QTc) > 500 msec.

At the three-month follow-up, three children reported sequelae: An infant with bronchopulmonary dysplasia who had increased need of long-term oxygen therapy; an adolescent with MIS-C and multi-organ dysfunction had significant weight loss, muscular atrophy and myocardial scar tissue detected by cardiac magnetic resonance; And the child with dilated cardiomyopathy and myocarditis had an unfavorable evolution due to worsening cardiac function requiring heart transplantation.

\section{DISCUSSION}

Studies from the US or China have demonstrated that children are overall less affected by COVID-19 and usually present with mild illness without the need for hospital care..$^{7-9}$ This tendency was also seen in our data, as $90 \%$ presented mild disease. Our data may overestimate serious presentations in children, as our hospital was the first tertiary pediatric hospital in Portugal receiving COVID-19 hospitalized patients from other regions of the country.

Currently, the main reason for starting an antiviral treatment is severe or critical illness, according to international guidelines, although differences between local guidelines and variation along the pandemic were noted..$^{13-15}$ Our initial approach was remarkably more invasive, in accordance with the first Chinese pediatric cohort that proposed infants as more prone to severe illness. ${ }^{20}$

Pre-existing medical conditions were initially proposed as likely major risk factors influencing and worsening patients' prognosis, especially in adults. ${ }^{22}$ Children with obesity, severe genetic, neurologic, respiratory and metabolic disorders, congenital heart disease, diabetes, asthma, and secondary immunosuppression were considered at risk for severe COVID-19. ${ }^{22}$ However, according to the Centers for Disease Control and Prevention (CDC), there is limited data 
about the impact of underlying medical conditions and the increased severity of COVID-19. ${ }^{22}$ In the initial phase of our study, patients with comorbidities were treated even if the symptoms were mild. Throughout the last four months, as clinical experience was gained, we changed our treatment approach and started to put more emphasis on severe disease instead of previous risk factors, except in cases of severe comorbidities, such as complex congenital cardiopathies.

Looking at our population, three out of four ICU admitted patients had comorbidities, warning us that prior clinical conditions might still predispose patients to severe presentations. In addition, Gotzinger $\mathrm{F}$ et al has seen an association between comorbidities and ICU admissions. ${ }^{8}$

Coinfections have been proposed as a co-factor for treatment and prognosis as they have been associated with severe cases. ${ }^{23}$ In our study, it is important to understand that clinical severity could have been associated with co-infecting microorganisms and not necessarily due to COVID-19. Therefore, it is crucial to understand the impact of co-infection in disease progression and severity and, consecutively, in the treatment approach.

In the literature, the laboratory parameters have been related with a worse prognosis, ${ }^{24}$ including lymphopenia, elevated CRP, LDH, D-dimers, fibrinogen, ferritin, procalcitonin, interleukin-6 (IL-6), BNP. As such, in our study, the children proposed for antiviral treatment had most of these parameters altered, which might be associated to disease severity. Moreover, elevated BNP presented a statistically significant association with treatment (Table 3 ).

Chest CT-scan abnormalities present a large variability as they have been seen even in asymptomatic patients and can overlap with other viral infections. ${ }^{25}$ Therefore, radiological findings of pneumonia can help stratifying risk and disease progression, but the treatment decision must be done according to both clinical severity and imaging findings. ${ }^{25}$

$\mathrm{HCQ}$ was the most frequently used antiviral especially during the first two months of the pandemic in Portugal (March and April), just like in other institutions in Europe, ${ }^{8}$ according to the available experience. ${ }^{13}$ However, the current findings are controversial. The efficacy of HCQ was not proven and the benefits in vivo are still not known. ${ }^{26}$ Our experience with $\mathrm{HCQ}$ included patients with mild illness and comorbidities, moderate and severe cases, and one critical patient, all leading to a full recovery. Clinical trials in pediatrics might have had different results as infections were less complicated compared to adults, demystifying the possibility of different treatment responses between adults and children.

Eight patients received LPV/r, all with favorable clinical prognosis. LPV/r was, initially, an alternative treatment for COVID-19 as it showed differences in mortality in SARS-CoV infection and in vitro activity against MERS-CoV. ${ }^{13}$ However, until now, and despite the promising evolution of our patients when administered during the first 96 hours of disease, little evidence of its benefits in vivo has been found. ${ }^{27}$
The WHO discontinued $H C Q$ and $L P V / r$ treatment as arms for COVID-1926 converting remdesivir to our current, main antiviral weapon against this disease. Wang $Y$ et a $1^{17}$ and Beigel $\mathrm{J}$ et $a^{28}$ showed that remdesivir presents benefits on shortening recovery from COVID-19 in clinical trials under oxygen or IMV. Regarding patients admitted to the $I C U$, Pasquini $Z$ et a ${ }^{29}$ states that this drug might be associated with a significant beneficial effect on survival. However, it was also observed by Spinner $C$ et a ${ }^{\beta 0}$ that a 10-day course of remdesivir, did not make a significant difference in the clinical status of patients with moderate disease. Clinical trials of remdesivir are still ongoing, including in pediatrics. ${ }^{19}$

Remdesivir is available in Portugal for patients who fit the criteria of evidence of COVID-19 pneumonia with positive SARS-CoV-2 PCR, receiving oxygen due to low peripheral oxygen saturation $\left(\mathrm{SpO}_{2}<94 \%\right){ }^{16,31}$ It was used in our hospital in three critical patients who had these criteria with a diagnosis of MIS-C and ARDS. It can be given to adults and children older than 12 years of age or with a weight over $40 \mathrm{~kg}$, and it can also be prescribed for off-label use in patients younger than 12 years old or with a weight between 3.5 and $40 \mathrm{~kg}{ }^{16,31}$ Therefore, infants and children who are suitable for off-label use prescribing might not be able to receive this therapy in time, while waiting for permission related with off-label treatment.

The effectiveness of adjuvant therapies with NHIG is being evaluated in various randomized clinical trials but still no quality evidence is available. ${ }^{13}$ However, the main focus of using NHIG was, in our department and abroad, not only in ARDS $^{32}$ but also in MIS-C cases due to the presence of immune dysregulation and its similarities to atypical-Kawasaki disease, which makes this therapy a crucial treatment in critical cases..$^{33}$ Other immunomodulatory therapies are corticosteroids, such as dexamethasone, which has shown promising results in reducing death in the advanced phases of the disease in adults, including patients receiving oxygen or IMV but not in patients with no respiratory support. ${ }^{18} \mathrm{We}$ have used MPDN in three patients: one with ARDS, given our previous experience with this drug use and as an alternative for dexamethasone ${ }^{34}$ and two with MIS-C to control the inflammation. Recent findings have demonstrated that MPDN in an early stage of the disease, in low-dose and short-term administration is associated with better clinical outcomes, such as the more rapid resolution of hypoxia, a lower need for IMV, and a shorter hospital stay, ${ }^{34}$ making this immunomodulator a promising treatment in managing severe COVID-19 cases.

Finally, in adults, the thrombotic risk related with COVID-19 has been stated and the use of anticoagulant therapy appears to be associated with a better prognosis. ${ }^{35}$ There are only a few guidelines regarding anticoagulation in COVID-19 and none of them applies to pediatric patients. ${ }^{36}$ Therefore, we only proposed the use of thromboprophylaxis in immobilized hospitalized adolescents with severe to critical disease. 
Table 6 - Proposal for the therapeutic approach of hospitalized children with COVID-19

\begin{tabular}{|c|c|}
\hline $\begin{array}{l}\text { Support therapy } \\
\text { - Oxygen } \\
\text { - Inhaled bronchodilators } \\
\text { - Inhaled corticosteroids } \\
\text { - Invasive mechanical ventilation } \\
\text { - Inotropic support }\end{array}$ & $\begin{array}{l}\text { Therapy should focus, at first, in this stage, including: } \\
\text { - Clinical surveillance } \\
\text { - Clinical stabilization } \\
\text { - Monitoring of symptoms and clinical evolution }\end{array}$ \\
\hline $\begin{array}{l}\text { Antiviral therapy } \\
\text { - Remdesivir }\end{array}$ & Consider in severe and critical cases according to WHO criteria ${ }^{15}$ (Table 1) \\
\hline $\begin{array}{l}\text { Immunomodulatory therapy } \\
\text { - Methylprednisolone } \\
\text { - Immunoglobulin }\end{array}$ & $\begin{array}{l}\text { Consider in cases of: } \\
\text { - MIS-C } \\
\text { - ARDS }\end{array}$ \\
\hline $\begin{array}{l}\text { Prophylactic anticoagulants } \\
\text { - Enoxaparin }\end{array}$ & $\begin{array}{l}\text { In selected cases: } \\
\text { - In severe or critical cases in which thrombotic risk is stated. }\end{array}$ \\
\hline $\begin{array}{l}\text { Antibiotics } \\
\text { - Amoxicillin/acid clavulanate } \\
\text { - Azithromycin } \\
\text { - Ceftriaxone }\end{array}$ & $\begin{array}{l}\text { In selected cases: } \\
\text { - If bacterial infection suspected }\end{array}$ \\
\hline
\end{tabular}

Secondary adverse drug reactions were only found in HCQ and LPV/r. Only two patients had to suspend antiviral therapy, suggesting that, overall, antivirals seem safe in children. However, the use of HCQ was always under clinical surveillance through medical protocols regarding cardiotoxicity as we have done in our department.

Although three patients reported post-discharge sequelae, most children fully recovered from the disease and hospitalization. This was also seen in other European countries, ${ }^{8}$ sustaining that COVID-19 is, in general, a benign viral disease in the pediatric population. Caution is needed nonetheless, and the long-term evolution, especially in those with pneumonia, is still not known. ${ }^{37,38}$

The clinical and therapeutic approach of hospitalized COVID-19 patients in our hospital have changed over time, according to our growing experience and the most recent scientific data. In order to face this emergent disease, it was crucial to have a prompt treatment approach for severe and critical cases that included not only antiviral therapy but also immunomodulators, prophylactic anticoagulants, and other supportive treatment. Therefore, we suggest that treatment should be defined by several steps, as shown in Table 6 .

The main limitation of this study focuses on being a single center observational study. Furthermore, as a tertiary hospital, we received most of the moderate, severe, and critical cases from a significant part of our country, leading us to have more severe cases than expected. Regarding the use of antiviral therapy, it is important to understand that the favorable clinical evolution that we have observed can also be related with the natural course of the disease or other variables that were not studied. Finally, the fact that we were changing our approach along the way, led us to decide on different therapies at different times.

\section{CONCLUSION}

Our study represents one of the first pediatric cohorts of hospitalized COVID-19 patients in our country. As seen in cohorts from other countries, most children presented mild disease with a favorable clinical evolution. However, we observed a significant proportion of patients with severe and critical disease, such as pneumonia, sepsis, MIS-C and myocarditis, that was hospitalized and received treatment according to the most recent data by the time. Few postdischarged sequelae have been reported but follow-up reevaluation is needed in the future.

There is still scarce robust clinical evidence from most antiviral and immunomodulatory therapies, and the lack of clinical trials in pediatrics makes the definition of a treatment approach in children a real clinical challenge. More randomized studies are needed in order to understand the best treatment choice for our patients according to their clinical characteristics. Increasing our knowledge about this emergent disease will help us find weapons against the ongoing COVID-19 pandemic.

\section{PROTECTION OF HUMANS AND ANIMALS}

The authors declare that the procedures were followed according to the regulations established by the Clinical Research and Ethics Committee and to the Helsinki Declaration of the World Medical Association updated in 2013.

\section{DATA CONFIDENTIALITY}

The authors declare having followed the protocols in use at their working center regarding patients' data publication.

\section{COMPETING INTERESTS}

The authors have declared that no competing interests exist.

\section{FUNDING SOURCES}

No financial support was received by any author. 


\section{REFERENCES}

1. Wang D, Hu B, Hu C, Zhu F, Liu X, Zhang J, et al. Clinical characteristics of 138 hospitalized patients with 2019 novel coronavirus-infected pneumonia in Wuhan, China. JAMA. 2020;323:1061-9.

2. Zhu N, Zhang D, Wang W, Li X, Yang B, Song J, et al. A novel coronavirus from patients with pneumonia in China, 2019. N Engl J Med. 2020;382:727-33.

3. Zhou P, Yang XL, Wang XG, Hu B, Zhang L, Zhang W, et al. A pneumonia outbreak associated with a new coronavirus of probable bat origin. Nature. 2020;579:270-3.

4. World Health Organization. WHO Director-General's Opening Remarks at the Media Briefing on COVID-19. [accessed 2020 Apr 22]. Available from: https://www.who.int/dg/speeches/detail/who-director-general-sopening-remarks-at-the-media-briefing-on-covid-19---11-march-2020.

5. Direção-Geral da Saúde. Ponto da situação atual em Portugal. 2020. Updated on 2020 July 7. [accessed 2020 Jul 07]. Available from: https:// covid19.min-saude.pt/ponto-de-situacao-atual-em-portugal/.

6. World Health Organization. WHO coronavirus disease (COVID-19) dashboard. [accessed $2020 \mathrm{Jul}$ 07]. Available from: https://covid19. who.int/?gclid=Cj0KCQjwirz3BRD ARIsAImf7LNEH6FXpBrmqvaUI pYiPr1W42Jne33Qkp5MjeWj6I8un8LnDGPAJcaAvJXEALw_wcB.

7. Centre for Disease Control and Prevention. COVID-19 Response Team. Coronavirus disease 2019 in children - United States, February 12April 2, 2020. [accessed 2020 May 07]. Available from: https://www.cdc. $\mathrm{gov} / \mathrm{mmwr} /$ volumes/69/wr/mm6914e4.htm?s_cid=mm6914e4w.

8. Götzinger F, Santiago-García B, Noguera-Julián A, Lanaspa M, Lancella L, Carducci FC, et al. COVID-19 in children and adolescents in Europe: a multinational, multicentre cohort study. Lancet Child Adolesc Health. 2020;4:653-61.

9. Shekerdemian L, Mahmood N, Wolfe K, Riggs B, Ross C, McKiernan C, et al. Characteristics and outcomes of children with coronavirus disease 2019 (COVID-19) infection admitted to US and Canadian pediatric intensive care units. JAMA Pediatr. 2020;174:868-73.

10. World Health Organization. Multisystem inflammatory syndrome in children and adolescents temporally related to COVID-19. Scientific Brief. 2020. [accessed 2020 May 18]. Available from: http://www.who.int/ news-room/commentaries/detail/multysitem-inflammatory-syndrome-inchildren-and-adolescents-with-covid-19.

11. Ahmed M, Advani S, Moreira A. Multisystem inflammatory syndrome in children: a systematic review. EClinicalMedicine. 2020;26:100527.

12. Sanders J, Monogue M, Jodlowski T, Cutrell J. Pharmacologic treatments for coronavirus disease 2019 (COVID-19): a review. JAMA. 2020;323:1824-36.

13. Pan American Health Organization. Ongoing living update of potential COVID-19 therapeutics: summary of rapid systematic reviews. [accessed $2020 \mathrm{Jul}$ 07]. Available from: https://www.paho.org/en/ documents/ongoing-living-update-potential-covid-19-therapeuticssummary-rapid-systematic-reviews.

14. Tobaiqy M, Qashqary M, Al-Dahery S, Mujallad A, Hershan A, Kamal M, et al. Therapeutic management of patients with COVID-19: a systematic review. Infect Prev Pract. 2020;2:100061.

15. World Health Organization. Clinical management of severe acute respiratory infection (SARI) when COVID-19 disease is suspected. Interim guidance. [accessed 2020 Apr 22]. Available from: https:// www.who.int/publications-detail/clinical-management-of-severe-acuterespiratory-infection-when-novel-coronavirus-(ncov)-infection-issuspected.

16. Direção-Geral da Saúde. Norma 004/2020: COVID-19: fase de mitigação. Abordagem do doente com suspeita ou infeção por SARSCoV-2. [accessed 2020 Oct 15]. Available from: https://www.dgs.pt/ directrizes-da-dgs/normas-e-circulares-normativas/norma-n-0042020de-23032020.aspx.

17. Wang Y, Zhang D, Du G, Du R, Zhao J, Jin Y, et al. Remdesivir in adults with severe COVID-19: a randomised, double-blind, placebo-controlled multicentre trial. Lancet. 2020;395:1569-78.

18. RECOVERY Collaborative Group; Horby P, Lim W, Emberson J, Mafham M, Bell J, et al. Dexamethasone in hospitalized patients with COVID-19 - preliminary report. N Engl J Med. 2020 (in press). doi: 10.1056/NEJMoa2021436.

19. U.S. National Library of Medicine. Remdesivir | Recruiting, active, not recruiting, dompleted, enrolling by invitation, terminated, withdrawn, unknown status studies | Covid19. [accessed 2020 Oct 09]. Available from: https://clinicaltrials.gov/ct2/results?term=Remdesivir\&cond=
Covid $19 \&$ flds $=a b y \&$ Search $=$ Apply $\&$ recrs $=a \&$ recrs $=f \&$ recrs $=d \&$ recrs $=h \&$ recrs $=e$ \&recrs=i\&recrs=m\&age_v=\&gndr=\&type=\&rs $\mid t=$.

20. Dong $\mathrm{Y}, \mathrm{Mo} \mathrm{Y}, \mathrm{Hu} \mathrm{Y}$, Qi $\mathrm{X}$, Jiang F, Jiang Z, et al. Epidemiology of COVID-19 Among Children in China. Pediatrics. 2020;145:e20200702.

21. Centre for Disease Control and Prevention. Coronavirus Disease 2019 (COVID-19) - People with certain medical conditions. [accessed 2020 Oct 09]. Available from: https://www.cdc.gov/coronavirus/2019-ncov/ need-extra-precautions/people-with-medical-conditions.html.

22. American Academy of Paediatrics. Multisystem inflammatory syndrome in children (MIS-C) interim guidance. 2020. [accessed 2020 Oct 09]. Available from: https://services.aap.org/en/pages/2019novel-coronavirus-covid-19-infections/clinical-guidance/multisysteminflammatory-syndrome-in-children-mis-c-interim-guidance/.

23. Yang $X, Y u Y, X u J$, Shu $H$, Xia J, Liu $H$, et al. Clinical course and outcomes of critically ill patients with SARS-CoV-2 pneumonia in Wuhan, China: a single-centered, retrospective, observational study. Lancet Respir Med. 2020;8:475-81.

24. Zeng F, Huang Y, Guo Y, Yin M, Chen X, Xiao L, et al. Association of inflammatory markers with the severity of COVID-19: a meta-analysis. Int J Infect Dis. 2020;96:467-74.

25. American College of Radiology. ACR recommendations for the use of chest radiography and computed tomography (CT) for suspected COVID-19 infection. [accessed 2020 Oct 10]. Available from: https:// www.acr.org/Advocacy-and-Economics/ACR-Position-Statements/ Recommendations-for-Chest-Radiography-and-CT-for-SuspectedCOVID19-Infection.

26. World Health Organization. WHO discontinues hydroxychloroquine and lopinavir/ritonavir treatment arms for COVID-19 - 4 July 2020 - News release. [accessed $2020 \mathrm{Jul}$ 16]. Available from: https://www.who.int/ news-room/detail/04-07-2020-who-discontinues-hydroxychloroquineand-lopinavir-ritonavir-treatment-arms-for-covid-19.

27. Cao B, Wang Y, Wen D, Liu W, Wang J, Fan G, et al. A trial of lopinavirritonavir in adults hospitalized with severe covid-19. N Engl J Med. 2020;382:1787-99.

28. Beigel J, Tomashek K, Dodd L, Mehta A, Zingman B, Kalil A, et al. Remdesivir for the treatment of Covid-19 - final report. N Engl J Med. 2020;383:1813-26.

29. Pasquini Z, Montalti R, Temperoni C, Canovari B, Mancini M, Tempesta $M$, et al. Effectiveness of remdesivir in patients with COVID-19 under mechanical ventilation in an Italian ICU. J Antimicrob Chemother. 2020;75:3359-65.

30. Spinner CD, Gottlieb RL, Criner GJ, López J, Cattelan A, Viladomiu A et al. Effect of remdesivir vs standard care on clinical status at 11 days in patients with moderate COVID-19: a randomized clinical trial. JAMA. 2020;324:1048-57.

31. U.S. Food and Drug Administration. Fact sheet for Health care providers emergency emergency use authorization (EUA) of remdesivir (GS$5734^{\mathrm{TM}}$ ). [accessed 2020 Oct 09]. Available from: https://www.fda.gov/ media/137566/download.

32. Cao W, Liu X, Bai T, Fan H, Hong K, Song H, et al. High-dose intravenous immunoglobulin as a therapeutic option for deteriorating patients with coronavirus disease 2019. Open Forum Infect Dis. 2020;7:ofaa102.

33. Hennon T, Penque M, Abdul-Aziz R, Alibrahim O, McGreevy M, Prout $A$, et al. COVID-19 associated multisystem inflammatory syndrome in children (MIS-C) guidelines; a Western New York approach. Prog Pediatr Cardiol. 2020 (in press). doi: doi: 10.1016/j.ppedcard.2020.101232.

34. National Institutes of Health. COVID-19 treatment guidelines panel. Coronavirus disease 2019 (COVID-19) treatment guidelines. [accessed 2020 Oct 9]. Available from: https://www.covid19treatmentguidelines. nih.gov/.

35. Tang N, Bai H, Chen X, Gong J, Li D, Sun Z. Anticoagulant treatment is associated with decreased mortality in severe coronavirus disease 2019 patients with coagulopathy. J Thromb Haemost. 2020;18:1094-9.

36. Loi M, Branchford B, Kim J, Self C, Nuss R. COVID-19 anticoagulation recommendations in children. Pediatr Blood Cancer. 2020;67:e28485.

37. Cuker A, Tseng E, Nieuwlaat R, Angchaisuksiri P, Blair C, Dane K, et al. ASH guidelines on use of anticoagulation in patients with COVID-19. [accessed on Oct 09]. Available from: http://www.hematology.org/ COVIDguidelines.

38. Fraser E. Long term respiratory complications of COVID-19. BMJ. 2020;370:m3001. 